03
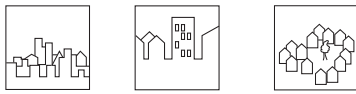

\title{
EXPLORATIONS ON RESIDENTIAL RESILIENCE
}

\section{Brf Viva 2011-20191}

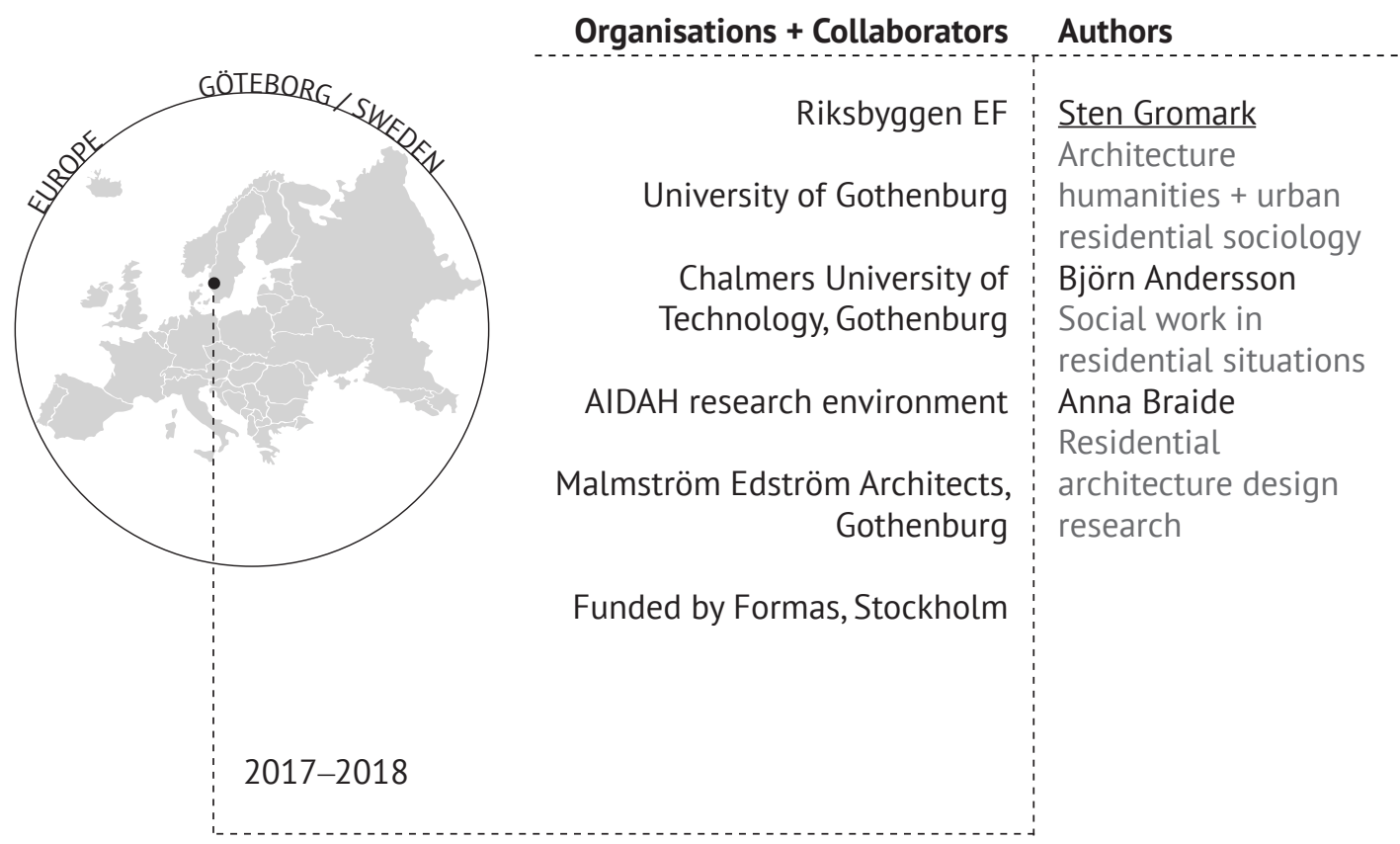

\section{Introduction}

Demands on housing providers are persistently mounting, urging them to confront current challenges of social sustainability in residential situations and to deliver practical contributions, demonstrations and experiments in this field. ${ }^{2}$ One such example in Sweden has been initiated as a research-informed project development process by the cooperative housing company Riksbyggen $\mathrm{EF}^{3}$ in Göteborg, Sweden. This organisation is also a major actor at the national level with its historical origin and legacy embedded in early working-class movements confronting the shortage of housing, starting to build in 1941. The type of enterprise is defined as a "cooperative economic association." In the following case assessment, it is considered as the major enabling and initiating factor, strongly supported by an academic environment. ${ }^{4}$

Over a period of eight years, since its start in 2011, a co-design process of a transdisciplinary (TD) kind has been jointly unfolded. To support professional actors from Riksbyggen in this innovative

FIGURE II.3.1 Bird's eye overview, brf Viva on Chalmers campus. Photo by Tomorrow/Riksbyggen EF/ Malmström Edström Arkitekter. 
effort, the process involved interdisciplinary (ID) exchanges between different expertises and academic actors of Chalmers University of Technology in general and the Department of Architecture in particular, as well as researchers at the University of Göteborg. With building starting in October 2016, the urban residential block will offer 132 apartments in total, situated on high ground in the direct vicinity of Chalmers campus. The first residents were moving in by late autumn 2018. The last phase of delivery of apartments and final inauguration date for the entire project was set for late summer 2019.

The finalised residential project will be considered the first result of the process initiated, the so-called Positive Footprint Housing ${ }^{\complement}$ effort, also known as PFH for short. This research and innovation project, jointly initiated by the company and its academic partners, includes the realisation of a number of radical innovations as part of a co-design strategy for sustainability. The multifarious methods of construction enacted are intended to demonstrate explorations of a significantly raised residential resilience embedded in brf Viva, the name later given to the cooperative association and future residential community. ${ }^{5}$

Examples of implementations of substantial technical innovations, or applied procedures, range from an exceptionally wide variety of components like the sharing of an electric vehicle pool with no conventional parking lots as a radical exemption from regulations, extensive application of façade and rooftop photovoltaic cells, and local electricity production with energy storage components. But also included are inventive acts of social solidarity and justice such as the introduction and integration of six affordable starter rental flats for young professionals. Added to this, the extended structural flexibility or long-term alterability of apartments with reduced floor areas is particularly featured, also providing the offer of extensive shared facilities such as a winter garden orangery for parties, meetings and cultivation of plants and vegetables. A significant feature has also been the ambition to introduce the project in an open dialogue with the local community. Efforts to create socially sustainable solutions have thus been both substantial and procedural in character.

The intricate process that was unfolded of a transdisciplinary dialogue of exchange within Positive Footprint Housing $@$ between different partners and stakeholders, academic and professional, even extended to local inhabitants and future residents, may be considered the very key to the alleged virtual success of the project. It has made it possible, specifically through the tentative exploration of new ways of knowledge co-production (Doucet \& Janssens, 2011), to materialise far-reaching new residential qualities realised within a context of high-profile sustainable performance, in social and ecological as well as in economic terms. However, the actual impact of all these arrangements upon members of the future residential community is still to be properly assessed in post-occupancy enquiries already outlined by Riksbyggen. How, whether and to what extent has this unique occasion significantly transformed ways of residing $g^{6}$ in terms of behaviour, resulting in the desired enhanced resilience?

The participating professional profiles and knowledge cultures involved are project leadership, initiation and production, selling, maintenance, and branding; in total, practically all branches of the established local unit of the Riksbyggen offices. This local team was complemented with national-level head office expertise, especially concerning sustainability matters as a main guiding force. The design knowledge skills and the experience in residential design was represented by the commissioned local architects with supporting landscape design expertise. The commissioned architects were Malmström Edström Architects and landscape architects were o2landskap.

The added academic counterpart provided different insights on residential design research issues from a social perspective, combined with experience from residential design research and practice, social work and participatory processes. On top of that, in different phases of the project, various 
kinds of relevant technological expertise from other departments of Chalmers or from private consulting branches were also engaged, concerned with, for example, local energy production, structural engineering or small electric vehicles and mobility issues. They delivered reports on different topics as preparation for the building construction phase and decisions to be made. These commissions were lined up primarily along the themes of social, ecological or economic sustainability. As an example, a special study was commissioned to cover the economic feasibility of the cooperative ownership and maintenance of the residential community to be created. Another study provided a referential overview of the state of the art of similar best sustainable residential practices in a global perspective. Yet another was commissioned for researchers of consumer sciences to carry out indepth interviews and an enquiry on future residents in the buildings, departing from an anthropological perspective.

This chapter will take a critical stance towards the endeavour described above and will build upon related research conducted with insights and observations shared by the three authors while taking part almost from the very beginning, participating within this process of research-informed residential project realisation. The focus for us was set to identify crucial social aspects of sustainability as social solidarity and related architectural residential configurations of design; in particular, those relevant for long-term alterability and short-term instant structural adaptability or immediate flexibility. Throughout this process, the inherent vagueness of general formulations of sustainability, predominant from the beginning, especially concerning social sustainability, was made very clear to all. This also underlines the importance of undertaking inter- and transdisciplinary research directly in the conflicting social fabric, where sustainable goals are negotiated and given a concrete, substantial significance.

The chapter ultimately intends to provide an initial critical reassessment of this whole process with an extended special focus on the evaluation of the outcome and value of the project from a transdisciplinary and interdisciplinary - even from an intradisciplinar ${ }^{7}-$ point of view.

However, the Positive Footprint Housing ${ }^{\complement}$ process and the brf Viva project are also regarded from a perspective of sustainability, as this process and its results, in our understanding, can be conceived and tentatively interpreted as the implementation of new modes of knowledge production, which are particularly dedicated to enabling the realisation of resilient new ways of residing. This was, for example, confirmed and underlined with emphasis by one of the responsible architects of the project; in his perspective, this was quite an unusual approach, a definite far cry from any conventional procedure in similar consulting situations. He went on to say that even if brf Viva could perhaps not be regarded, as alleged, as the best practice of its kind in a global context, it certainly attempted the most numerous, complete and diverse avenues of approach and practical realisations in one single project. ${ }^{8}$

\section{Initiating a Situation of Transdisciplinary Exploration}

Chalmers University of Technology, and in particular the School of Architecture, has developed, step by step, in Master's education studios and in related research projects, a specific strategy for transdisciplinary cooperation between university research and education, commercial private businesses and in particular - as well as in contrast to other parts of Chalmers - public societal institutions such as municipalities and regional governments. ${ }^{9}$ 
Due to this long-established orientation, it came as a natural and most welcome occasion in 2011 when the cooperative housing provider Riksbyggen EF presented the school with an invitation to take part in a long-term development project, at that time coined Positive Footprint Housing ${ }^{\complement}$, which was later also registered as a branded business trademark. This initiative was related to the ambition to unfold a research-informed experimental housing project almost directly on campus.

In general terms, this step could be conceived as the growing recognition and validity of researchinformed support in efforts to develop a different business activity. But it also originated from a manifest search for a more distinguished sustainable business profile, to follow up on evidently slowly emerging but fragmented new consumer demands and the mission to reveal appropriate, attractive and unique offers on the market.

Riksbyggen EF had thus taken a crucial step towards the strategic decision to actively support resilient residential invention. This was conceived as part of their strong general commitment to construct a sustainable urban development agenda built around specific "in-house" assessment tools of measuring sustainable performance alongside the already established ones such as BREEAM ${ }^{10}$ and others. In this case, the social aspects were put in specific focus with great emphasis. In this situation, the company was acting locally as a progressive forerunner at the national level, breaking barriers, while Riksbyggen is considered one of the biggest cooperative housing providers in the country second only to the bigger and similar HSB cooperative organisation - with 176,000 units in 2,730 cooperative associations, with about 350,000 individuals involved. ${ }^{11}$

For the envisaged cooperation with academia, Riksbyggen EF offered essential resources for a PhD position, extended to four years' part-time study, intended to finally result in a licentiate degree. In addition, other related resources were provided for preparatory studies supporting the project. On their side, the school offered the general support of in-kind commitment of involved professors and researchers ${ }^{12}$ and by specifically dedicating the two Master's studios directly involved ${ }^{13}$ to provide inspiring reflections on the project from different and alternative points of view, in parallel to the actual professional design process. The initiated $\mathrm{PhD}$ licentiate project was oriented early on towards a discussion on apartment-level alterability that was later practically implemented on-site, considered as structural flexibility and as a largely so far ignored aspect of residential quality of life in terms of social sustainability. ${ }^{14}$

After the initial contract procedures, there followed a long series of meeting engagements between different constellations of academic, institutional and business stakeholders in a process of enhanced dialogue, during which members were resolving differences and crossing professional and academic boundaries. With meetings about every second month, this finally ended up in a constructive climate of creative co-design, mutual trust and a distinct common culture of commitment to the cause.

The partners primarily included members of the Riksbyggen EF project organisation with its different departments such as the commercial and technical branches, and persons representing local and to some degree regional and even national leadership, such as the head sustainability assessment officer from the Stockholm headquarters; and the academic departments of Chalmers School of Architecture - and several other departments - with involved professors, teachers, the committed $\mathrm{PhD}$ candidate and a succession of indirectly participating Master's studio students from about three consecutive academic years, revealing their designs for the site, inviting the project leaders from Riksbyggen to take part in public exhibitions and critical assessment sessions, along with a number of related Master's thesis projects. ${ }^{15}$ Thus, the spirit of a transdisciplinary culture of knowledge production was transferred to several new generations of young architects. So, one of the important criteria for transdisciplinarity was fully met in this situation, since the project team not only included exchanges 
between professionals and academics but also reached Master's-level students, in many cases coming from several foreign countries. On top of this, there were also, on many special occasions, a variety of experts and consultants present with insights into, for example, energy systems, photovoltaic cells, alternative electric vehicles, principles of sustainable development at large and so forth.

Researchers from social work and researchers in economics from the local business school were also represented as well as, sometimes, invited guests from abroad. One particular arranged session assembled a number of local influential architects to discuss the preliminary designs, providing a critical external eye as a sort of occasion for self-criticism. Added to this, in the early phases, before the building permit was acquired and the detailed plan adopted, the representatives of the technical departments of the city of Göteborg and the commissioned team of architects and landscape architects were also taking an active part. It could be added that the team of architects won the commission at a very early stage in the process, almost before it started. This was because the architects qualified for the commission by winning an earlier design competition for Riksbyggen on another project site that was later abandoned and replaced with the present location.

Three things are important in order to understand why this process worked in a transdisciplinary way. First, there was a high degree of continuity of individuals involved. This had the consequence that each meeting could simply start from the point where the last meeting ended; there was no need to update everyone. This was an important step to ensure the creation of a common project culture characterised by mutual trust. Second, there was a clear structure in the group concerning professional affiliation, competence and mission. It was never questioned why or on what mandate each person was there. Third, every member of the group was encouraged to comment and contribute to all issues, even when it was a question outside their personal field of competence. However, taking part in a discussion always meant maintaining one's expert position, not just talking about everyday life experiences. For all participants, it meant a particular learning experience and a significant merger of professional cultures. This is how disciplinary knowledge becomes fully cross-transactional.

This established extended dialogue at the crossroads between partners, stakeholders and different professional profiles, relevant for the planning process and the design, was also extended to a series of organised meetings with external local associations and neighbouring inhabitants in order to hear their opinion and to inform on the character of the project and the changes it would potentially induce, as well as the opportunities it would also eventually and desirably provide for those already living on neighbouring sites. On that point, towards the end, actually, there was unexpectedly very little opposition voiced nor major objections raised to the potential local negative impacts of the building designs during the formal planning process, such as, for example, effects of local densification or line-of-sight obstructions. This was in spite of the sensitive location and well-known proactive local commitments to the preservation of flora and fauna in this now ageing and waning local community of Guldheden with its prestigious and legendary classical welfare state origins of the late 40s and 50s. Furthermore, this part of the city is, by coincidence, intimately connected to well-known major national attempts at residential innovation, in particular due to the important seminal post-war housing exhibition Bo Bättre (Good Dwelling) in 1945. So, in this context, the brf Viva project can be regarded as the recurrence of similar radical ambitions now transferred to our contemporary reality.

This process of dialogue continued after the building project took off on its own track, even if the number of people participating at the table had diminished. If continued, this extended dialogue will offer an important opportunity to conduct a long-term follow-up and to draw conclusions derived from this project when households have taken residence and established themselves as a community 
within the building complex. But, as intended, and as common opinion seems to eagerly agree upon, it will also provide important lessons learned on how to establish such common ground and a common project culture, directed towards residential and resilient innovation, that will be useful in further projects coming up in the future. Actually, this situation has to some degree already occurred, with two new projects that have recently been initiated.

Positive Footprint Housing ${ }^{\complement}$ as a process is to be continued for a second ongoing project, this time concerned with residential solutions for young professionals with modest income levels. It also explores new communal ways of residing and sharing in Lindholmshamnen, located on another experimental site of the city, where lessons learned in brf Viva can be further fully exploited.${ }^{16}$ Moreover, a competition arranged by Riksbyggen has recently awarded and commissioned the residential project Slå Rot, featuring solid wood construction and recyclable building components as yet a third offspring of the Positive Footprint Housing $($ process.

This provides an image of how new knowledge is transmitted via the Positive Footprint Housing ${ }^{\complement}$ platform from project to project, as was initially intended, responding to the established model of coproduction of knowledge beyond disciplines, with regards to ways of continuation, implementation and generalisation.

So far, it is quite apparent that the transdisciplinary approach adopted in this case has, to a considerable extent, provided an efficient method to grasp and to integrate a wide spectrum of implementations of sustainable character, embracing the totality of a complex project development process. The dialogue planning procedural approach may be considered here as the key notion for the alleged success of the project and is soon, as mentioned above, to be tested again. ${ }^{17}$

\section{Innovative Features as Outcomes of the Project}

To illustrate the actual impact of transdisciplinarity and interdisciplinarity contributions in this case, we can immediately identify at least three such distinct components of the project as a whole. These are components that probably would not have been imagined nor realised, as things stand right now, if the process of mutual interdisciplinary exchanges had not been initiated. The first addresses the challenge of social solidarity and economic justice; the second the concept of preconceived long-term alterability and user-provided adaptability on the level of floor plans, considered as a crucial aspect of social sustainability; and the third a surprising example of major technical innovation concerning concrete construction dictated by concerns for sustainability and reduction of $\mathrm{CO} 2$ emissions.

\section{Six Apartments for Young Professionals: Accessibility and Affordability}

The first example concerns the six integrated one-bedroom flats that will be let with certain exceptional conditions. For these, the price of the share is set considerably lower than the market price, at c. $€ 9,500$. At the same time, the monthly rent is higher in comparison. These six apartments will not be available on the market, but offered to young professionals between 18 and 30 years old. The city administration of Göteborg will be involved in the selection of residents. Whoever moves in can also stay after they have turned 30, but the apartment will again be offered on these special conditions once someone moves away. The price of the share will then be calculated on an indexed basis, so that there will be no possibility for the shareholder to make a profit. The residents of these apartments will be full members of the cooperative housing association and will have the right to use all common areas and assets in the neighbourhood. 


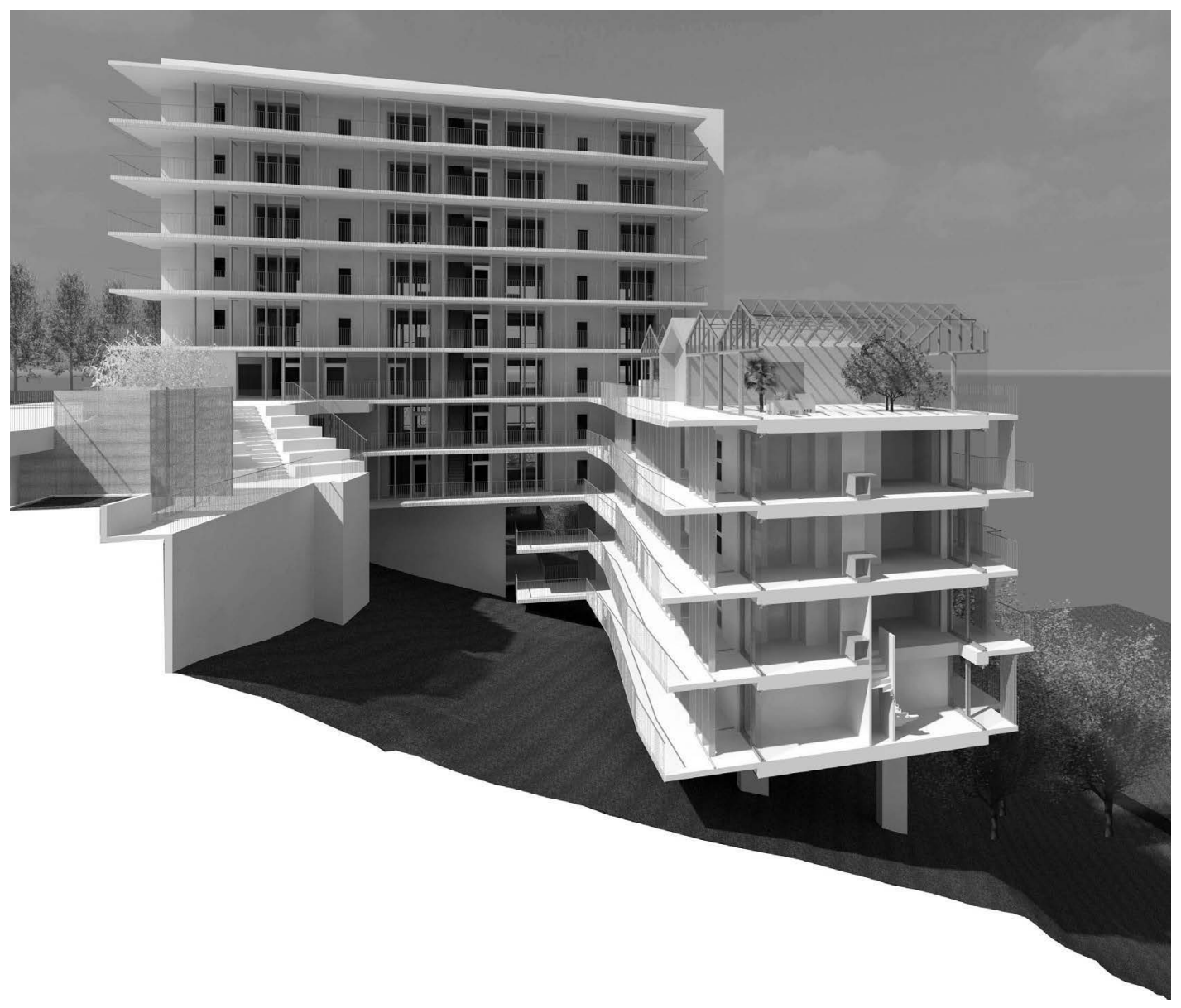

FIGURE II.3.2 Section cut. Outlines from the design process and not as being built. Source: Malmström Edström Arkitekter.

This construction of mixed "cooperative rental tenure" concerns only a small part of the total number of apartments, but represents a new model and a generally widely appreciated and celebrated attempt to contribute to more socially equalising solutions on the housing market. From a transdisciplinary perspective, these apartments are produced in an interface between social sustainability efforts, extraordinary juridical and economic solutions to the housing arrangements, architectural design efforts to achieve high residential value in a small space and, finally, the municipality organisation to select residents who fit the target group. It must be in doubt whether this formula could have possibly occurred without a research-informed process of project development combined with the dedicated commitment and action undertaken by one of the academic partners involved in the process. ${ }^{18}$ 


\section{1-1,5 RoK \\ $41,9 \mathrm{~m} 2$}

\section{2-4 RoK}

$67,5 \mathrm{~m} 2$

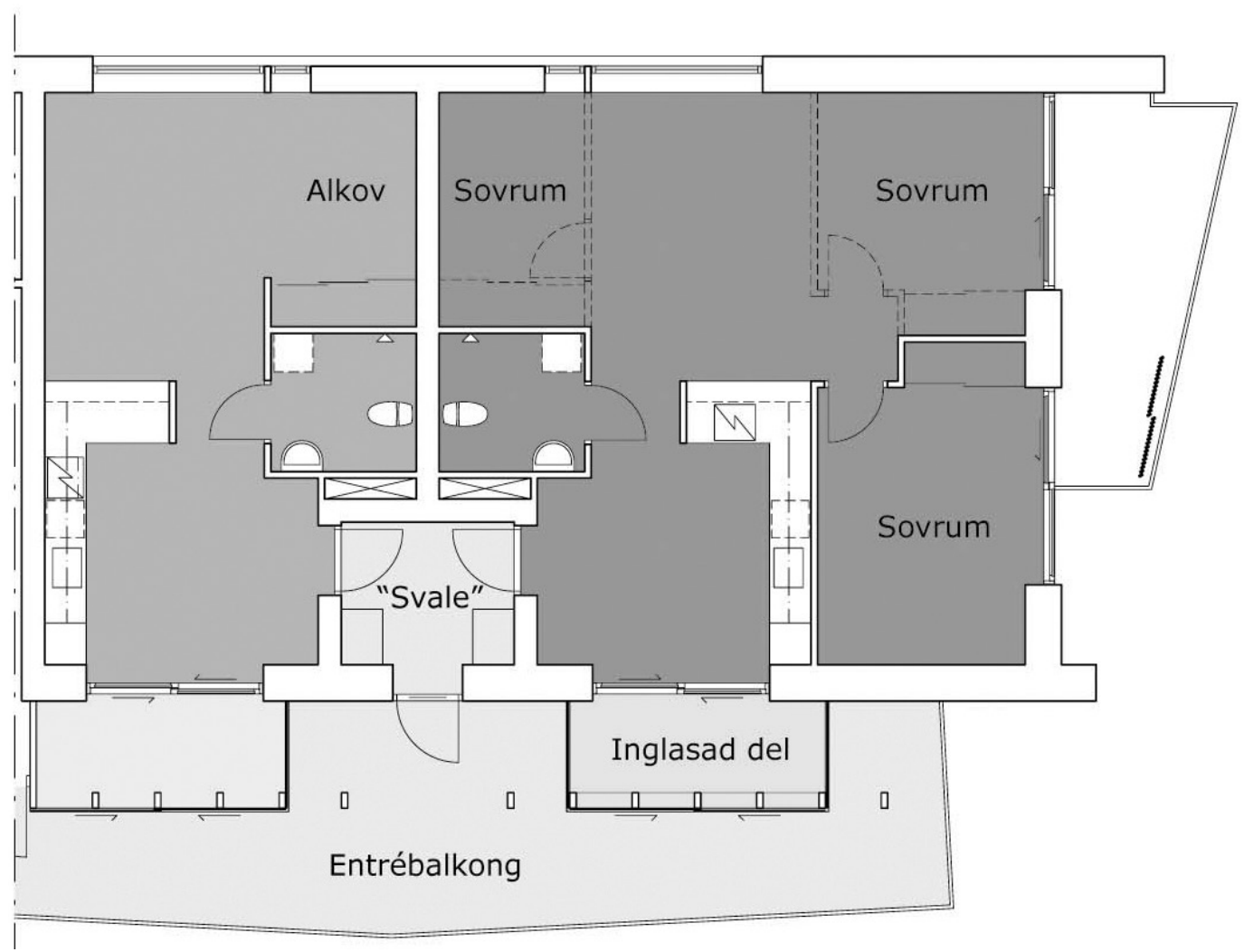

FIGURE II.3.3 Flexible apartment plan with adjacent apartment; 2, 3 or 4 rooms alternatives indicated. Outlines from the design process and not as being built. Source: Malmström Edström Arkitekter.

\section{Adaptable Apartment Design: Alterability, Adaptability and Flexibility}

The second example concerns flexible apartments. Larger apartments in the brf Viva condominium have been conceived to enable the residents to adapt their dwelling to their temporary, life situationdependent, residential needs. The potential ability to adapt to users' life situations or residential needs and desires is considered to be an important embedded quality of opportunity. In these apartments, the number of rooms can be adjusted from two to three or even four. This is accomplished by either adding or taking away interior walls. This design scheme, providing a variable number of rooms, has required a partly free-bearing construction and special attention to and adaptation of technical solutions for ventilation and electricity.

These flexible apartments are intended to contribute to an increased social sustainability by enabling a more variable use of the apartment over a longer time frame, which can offer a wider freedom for personal choices and an increased feeling of active participation in the residential situation as a creative, contributing user. 
The possibility of changing the number of rooms in the dwelling also opens up the capacity to host a larger diversity of household types, something that can eventually work for increased integration between varying household configurations. The variability of the number of rooms can also make it possible for the household to stay in the same dwelling when the family or household grows or shrinks. Apartments next to each other might even accommodate different forms of co-living together and independently at the same time as integrated ways of residing for the elderly. Over a prolonged time frame, this can provide a stronger and more lasting continuity and rootedness for the residents, as much within their own block as in the surrounding wider neighbourhood. It will potentially contribute to stronger social dimensions of safety, identity and social cohesion as well as longevity of community.

An enhanced diversity of residential solutions can also promote a more sustainable housing stock from the perspective of the ongoing demographic transformation processes. The future demographic structure is, despite the current prognosis, difficult to predict, as are future residential aspirations and lifestyle preferences that might be the object of significant and sudden changes in a longer time perspective. In this context, the flexible apartments can be conceived as more resilient than "normal" apartments with a low capacity of adaptability, as conceived for as yet unknown residential situations of the future.

As the ultimate major achievement of the transdisciplinarity process, the decision by Riksbyggen to include and to fully acknowledge the qualitative notion of alterability of apartments and buildings as a vital aspect of life cycle assessment ${ }^{19}$ or BREEAM sustainability assessment calculations in their own inherent "in-house" evaluation tool can be considered a significant change of orientation. ${ }^{20}$

\section{"Green" CO2 Neutral Concrete Framework as a Surprising New Option}

A major and crucial decision in any building project is the choice of a structural framework. In this case, concrete and solid laminated wooden structures were considered. From a sustainable point of view, solid wood has an advantage as a natural container of CO2, as very user friendly and it also carries a lot of other attractive sensuous and symbolic qualities when compared with grey concrete. So, early on during the process, the commission was given to two different providers to make a complete life cycle assessment (LCA) ${ }^{21}$ analysis of their respective offers of structures for the building complex. It appeared at first that the solid wood construction, cross-laminated timber (CLT), was considered to be significantly more sustainable than the concrete solution. However, the concrete industry then acted and said, "well, we do have other more advanced and more sustainable solutions, with lower CO2 emissions, but they are more time consuming, thus also costly." So, they came up with recalculations built upon a prolonged drying or hardening procedure to make the use of concrete almost equal with the wood alternative. ${ }^{22}$

Riksbyggen EF then felt free to decide in favour of the "green" concrete alternative, avoiding the more unknown and unproven prospect of solid wood, which had other potential problems to be dealt with, however cherished and desired that concept was for the time being in professional circles. Furthermore, the entrepreneur of the wooden cross-laminated timber system eventually also withdrew their offer late in the process.

This decision was later to be turned into a great success in the professional media coverage, putting the brf Viva innovative ambition in the public spotlight. The situation even produced repercussions in the industry on the national and Scandinavian levels to provide similar and better offers to reduce CO2 emissions from concrete to 30\%. This serves as an indicator of the level of innovation achieved in the process of project development due to the special and accentuated attention paid to the procedure as dominated by advanced concerns for sustainability. 


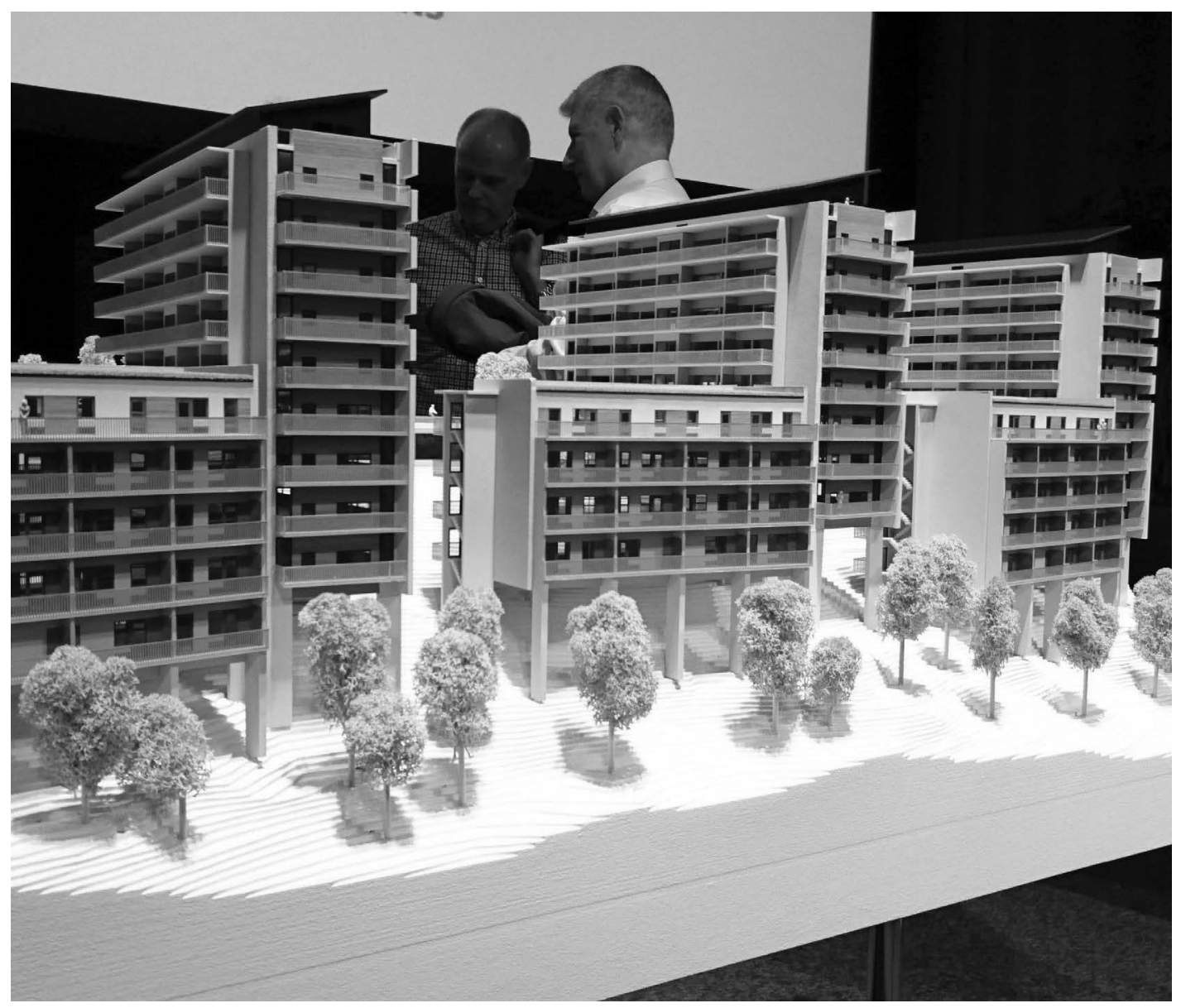

FIGURE II.3.4 Public Launch Project Model, 2 March 2016 by Riksbyggen EF. Construction start on 2 November 2016, 132 apartments in cooperative tenure with highest possible sustainable profile. Photo by Sten Gromark.

\section{Dissemination: Mediatic Acclaim and Recent European Union/ERA Recognition}

Beyond the focus placed on the unusual concrete solution projected in a number of recent Norwegian publications and other general newspaper publications, the project as a whole has so far received considerable recognition for its ambition to explore new ways of constructing residential resilience.

This may be a sign that confirms the perceived innovative profile of the project. It received, for example, an international prize awarded recently, distributed in Hong Kong, at the conference SBE17 in June 2017, as a result of a competition arranged by the Swedish Green Building Council, for one of the five best sustainable projects in Sweden. ${ }^{23}$ Another equally recent first prize award was achieved as nominee and winner of the Habitat of the Year 2018 in the Swedish magazine Rum - Arets bostad. $^{24}$

A main achievement of the project has been to become a part of the European Union Pilot and Experimentation project IRIS (2017-22), a European Union-level demonstration project. This is 
funded by high levels of European Union research and demonstration funds, with significant relevance in the ERA as recently signed with the European Commission under the title Integrated and Replicable Solutions for Co-Creation in Sustainable Cities, with a total budget of $€ 18$ million for five years. ${ }^{25}$ Ultimately, the project, as a major recognition, was awarded the prestigious Kasper Salin National prize for best architecture 2019.

\section{Assessment of the Intrepid Approach: Barriers, Enablers and Transferability}

In this project, the main barriers encountered consisted primarily of the restrictions put on the project from a strict commercial point of view. On many occasions, the leadership of Riksbyggen underlined that the limits of an experimental attitude or advanced realisation are delimited by the sheer necessity, in the end, of providing attractive offers to customers, so that apartments could be sold in spite of considerably high costs. Primarily, these were generated in particular by the difficulty of the drastically inclined rocky site of the project. This circumstance might have led to an invisible, cognitive barrier for a more daring, structurally radical, architectural and designerly approach. As close observers, we were confronted throughout the process by some opinions uttered considering the project not to be radical enough or even a mere commercial greenwash of a conventional kind, attracting a green middle-class affluent intelligentsia. ${ }^{26}$ But, for the Riksbyggen team, as the level of innovation had ultimately been fixed, what was at hand with all its complexities was still already an audacious, intrepid and big step out into the quite unknown, entirely uncharted terrain of taking modest, but if possible, well-measured risks for a much desired end result of a project that was sold out.

Concerning the main enablers of the project, it has been mentioned above that the decision to initiate the project fell on and grew out of fertile and thriving ground in the university context of Chalmers. The reception could be characterised by a readiness or preparedness to act in this direction well beyond academia, among teachers, researchers and even involved students. The situation provided an unusual, well-balanced meeting point, to promote an enhanced mutual cocreative understanding between academia and education reality on the one side and the professional and commercial reality of Riksbyggen with involved consultants on the other.

From the beginning, there was a lingering mutual curiosity or even a slight doubt on each respective side of the professional cultures. For Riksbyggen, this implied they should better understand the conditions in academia, and for researchers, to better understand commercial realities and the nature of the socially oriented ideology of the cooperative housing provider. But later on in the process, a distinct trust was created and a common project culture definitely took constructive and creative shape. This provided vital energy for the duration of the long process. It should also be noted that a distinct point of division was pronounced between the research process identified as Positive Footprint Housing ${ }^{(}$and the actual building project, brf Viva, when it was started.

Concerning transferability, it has already been noted above that the Positive Footprint Housing $\mathbb{C}$ process has continued beyond the realisation of brf Viva in 2019 and has provided personal experiences of co-production of knowledge among the participants to be applied in further explorations of future building projects that have already been initiated. Themes envisaged are affordable apartments for young people, building in solid wood and also integrated residences for the elderly.

It is important to clarify that, throughout the process, researchers had the right to make suggestions and proposals but were never part of the actual building design process in responsible decisionmaking positions. Exchanges were very much focused on the highlighted demands of Riksbyggen to put priority on defining ways of promoting social sustainability, considered as a growing concern, 
while previously energy-saving solutions stood in the absolute foreground of attention in similar discussions. So, the main question put to researchers, constantly repeated, was about what constituted actions and means of social sustainability in this residential situation. The notion introduced concerning alterability of apartments has a key position in this regard, considered as a so far unexplored quality of residence in a wider time frame of enhanced resilience and longevity.

\section{Conclusions: A Transdisciplinary Dialogue Providing New Knowledge}

In sum, the process of transdisciplinarity as practised in this case represents, in a theoretical perspective, a fruitful occasion to commonly explore new modes of knowledge co-production as constructed around the building core project, the simulacrum, as a focused object of cultural negotiation (Conan, Gromark, Jantzen, \& Bilsel, 1998; Doucet \& Janssens, 2011; Gibbons et al., 1994; Hemström, 2018; Nilsson, 2004). It is perhaps too early to say what kind of knowledge has been created, but we can point to some particular illustrations - the small steps - that we find convincing as illustrations, as related above. First, the social justice perspective, applied as the six starter flats; second, the initiated discussion and actual implementation of flexible and alterable apartments considered as improving quality of life and as an aspect of social sustainability in a longer time frame; and third, finally, the technical invention of sustainable green concrete with low CO2 emission impact.

The transferability of the new knowledge so produced could be regarded as the experiences gathered from the method applied - the dialogue process - and the enhanced transdisciplinary exchanges between partners. Riksbyggen will definitely build further upon these experiences for future projects, one of which is already running with another set-up of partners, as noted above. ${ }^{27}$ More specific projectrelated knowledge, as mentioned above, concerning general availability and affordability, and alterability and adaptability of apartments, must be assessed in a longer time span after the end realisation and final appropriation of the project among local residents. In the case of promotion of green concrete, it has already had significant and widespread repercussions in the building industry in a situation where solid wood solutions are generally considered to be the given choice for sustainability reasons.

As more general themes, as reflections generated by our presence in this residential situation, we see an opportunity to rethink residential situations along the lines of alterability - projecting longevity and structural residential resilience into a longer time frame; adaptability - widening the offer of diversified household configurations of life projects; and finally, accessibility - providing occasions of inclusion for spatial residential explorations of life projects within reasonable economic limits of affordability.

The main prospect ahead for the future, beyond 2019, will be to see how the residential community now taking shape, the social subject of brf Viva, be prompted, in the long run, to explore resilient common ways of life and significant new ways of residing as a realisation of the main objective of the Positive Footprint Housing ${ }^{\complement}$ transdisciplinary knowledge co-production process - considered as a huge secondary social challenge behind the project within a far wider time frame.

\section{Acknowledgements}

This chapter contribution by authors to the European Union COST Action Intrepid and the participation in the Positive Footprint Housing $\bigcirc$ project was made possible by substantial support from Formas $^{28}$ of the AIDAH research environment at Chalmers ACE and through collaboration with and vital support also provided by Riksbyggen EF. 


\section{Notes}

1 This chapter builds upon a paper, awarded best conference paper, presented jointly by the authors in Porto, at the Green Lines Institute conference on Sustainable Housing (Andersson \& Gromark, 2016).

2 For two similar and typical building projects in Sweden see Xplorion featuring residential sharing solutions cf. http://futurebylund.se/project/ec2b retrieved 26 November 2018 and Cykelhuset Ohboy! (Bicycle house) on alternative mobility cf. Lidström (2017), https://www.boplatssyd.se/nyproduktion/ cykelhuset-ohboy retrieved 26 November 2018.

3 Ekonomisk Förening.

4 Actually, the project was personally initiated by an officer of an innovation centre at Chalmers in close cooperation with the regional Chief Executive Officer of Riksbyggen EF.

5 Brf is short for bostadsrättsförening (English: "co-operative tenure association" or housing association).

6 Gromark, Ilmonen, Paadam, \& Støa (2017).

7 Intradisciplinarity: internal, inward-directed, academic condensation, consolidation and reinforcement, theoretical and methodological, cf. a case related in (Gromark, Mack, \& Toorn, 2019).

8 Architect SAR/MSA Andreas Norrman in a lecture at Chalmers, 21 November 2018.

9 Cf. Roos (2017): Chalmers' strategy for interdisciplinary organisation in order to promote sustainability was initially inspired by the example of the Stanford Center on Longevity, an interdisciplinary strategy applied to improving residential healthcare conditions and quality of life for the elderly, supported by Chalmers' vice-dean Anna Dubois. The general conceptual approach towards futures of universities is to a large degree inspired by extensive writings on the topic by Professor emeritus John Goddard (cf.(Goddard \& Vallance, 2013).

10 Building Research Establishment Environmental Assessment Method (BREEAM).

11 In Sweden, $48 \%$ of the population live in multi-family, rental or co-operative housing, and $45 \%$ in singlefamily residences; single households maintain a constantly increasing percentage. Source: SCB.

12 Later in the process, the national research organisation Formas supported the Architecture in Effect and AIDAH projects and also guaranteed continuation of researcher participation for the $\mathrm{PhD}$ candidate engaged after she completed her licentiate thesis.

13 The Housing Invention Studio and the Matter, Space, Structure Studio.

14 The result is a licentiate thesis (cf. (Braide-Eriksson, 2016), developed further into a PhD thesis, defended in spring 2019 (Braide, 2019).

15 Such as, for example, (Anderberg \& Leffler, 2018; Axelsson, 2014; Granberg \& Mirjamsdotter, 2016).

16 http://lindholmshamnen.se/projektet/ retrieved 01 October 2017.

17 For the much featured concept of dialogue in the local planning context, cf. (Eriksson \& Nylander, 2016); and for an extensive account of application cases, cf. (Fröst, Lindahl, Eriksson, \& Gustavsson, 2017).

18 Riksbyggen, 2017.

19 Livscykelanalys (English: life cycle assessment (LCA)).

20 Current Swedish research at Chalmers confirms the importance of considerations of alterability among customers in situations purchasing a new apartment; cf. (Femenías, Holmström, Jonsdotter, \& Thuvander, 2016; Jonsdotter, Femenías, \& Holmström, 2016). In general, it is also an accepted and growing quality feature on the residential market, signalled by many other sources.

21 Cf. report presented at meeting, 25 January 2018; TEMA: Uppföljningen av Brf Vivas LCA; Slutrapportering 2018 (Eva-Lotta Kurkinen).

22 Brick, Johansson, Rönneblad, \& Kurkinen, 2017).

23 http://www.mynewsdesk.com/se/riksbyggen/pressreleases/brf-viva-utvald-att-representera-sverigepaa-internationell-konferens-i-haallbart-byggande-1954444 retrieved 26 August 2017.

24 (Masnic, 2018); http://www.mynewsdesk.com/se/riksbyggen/pressreleases/riksbyggens-brf-vivanominerad-till-aarets-boende-2018-2332904 retrieved 25 January 2018; https://www.mynewsdesk.com/ se/riksbyggen/images/bild-fraan-prisutdelningen-den-5-februari-paa-oscarsteatern-1203182 retrieved 08 February 2018.

25 http://www.iqs.se/om-oss/aktuellt/nyheter-2016/170927-iris/ retrieved 01 October 2017.

26 Question raised, for example, in the first public project presentation discussion on 02 March 2016 at Svenska Mässan, Göteborg. 
27 Affordable starter apartments for young professionals in Lindholmshamnen, with more than 200 units; and the solid wood experimental project, the winning competition entry Slå Rot by Sweco Architects and Cajsa Crona in 2017.

28 Formas: The Swedish Research Council for Environment, Agricultural Sciences and Spatial Planning.

\section{References}

Anderberg, E., \& Leffler, M. (2018). (Re)form the norm. A norm-creative design proposal in Majorna. Master of Architecture. Chalmers, Göteborg.

Andersson, B., \& Gromark, S. (2016). Social Sustainability in Residential Solutions - A Swedish Case. [Paper Presentation]. Paper presented at the Sustainable Housing 2016. International Conference on Sustainable Housing Planning, Management and Usability. Book of Abstracts. Porto, Portugal 16-18 November, Porto.

Axelsson, J. (2014). Together on our own: the meaning and position of the residential community. Master's Thesis. Chalmers Architecture MPARC, Göteborg.

Braide-Eriksson, A. (2016). Residential Usability and Social Sustainability. Towards a Paradigm Shift within Housing Design. Licentiate degree. Chalmers University of Technology, Göteborg Sweden.

Braide, A. (2019). Dwelling in Time. Studies on life course spatial adaptability. PhD. Chalmers ACE, Göteborg.

Brick, K., Johansson, A. C., Rönneblad, A., \& Kurkinen, E.-L. (2017). Klimatsmart och unik betong i Riksbyggen Brf Viva. Göteborg: Riksbyggen EF.

Conan, M., Gromark, S., Jantzen, E. B., \& Bilsel, C. (1998). Architects as Actors in Redevelopment of Urban Form in Municipalities. Research directed by Michel Conan, Cstb, Preliminary illustrated report Draft IV of EuroConception Research Project Version of September 1998. Paris: EuroConception.

Doucet, I., \& Janssens, N. (Eds.). (2011). Transdisciplinary Knowledge Production in Architecture and Urbanism. Towards Hybrid Modes of Inquiry. New York: Springer USA.

Eriksson, J., \& Nylander, O. (2016). Mer dialog med fler - verktyg för snabb planprocess. Stockholm: Svensk Byggtjänst förlag.

Femenías, P., Holmström, C., Jonsdotter, L., \& Thuvander, L. (2016). Arkitektur, materialflöden och klimatpåverkan i bostäder. E2B2 rapport. Stockholm: Energimyndigheten.

Fröst, P., Lindahl, G., Eriksson, J., \& Gustavsson, A. (2017). Designdrivna dialoger för arkitektur och samhällsbyggnad. Malmö: Sweco AB.

Gibbons, M., Limoges, C., Nowotny, H., Schwartzman, S., Scott, P., \& Trow, M. (1994). The New Production of Knowledge. The dynamics of science and research in contemporary societies. London: SAGE Publications.

Goddard, J., \& Vallance, P. (2013). The University and the City; 1st Edition. London: Routledge.

Granberg, J., \& Mirjamsdotter, H. (2016). Searching for Living Space - Socio-Spatial Explorations for Sustainability through Collaborative Residing. Master's Thesis. Göteborg: Chalmers Architecture.

Gromark, S. \& Andersson, B. (Eds.). (2020). Architecture for Residential Care and Ageing Communities: Spaces for Dwelling and Healthcare. New York: Routledge USA.

Gromark, S., Ilmonen, M., Paadam, K., \& Støa, E. (Eds.). (2017). Ways of residing in transformation - Interdisciplinary perspectives. (Re-edition in paperback.) (Ed.). London: Routledge.

Gromark, S., Mack, J., \& Toorn, R. v. (2019). Rethinking the Social in Architecture: Making Effects - Editors' Introduction. In S. Gromark, J. Mack, \& R. v. Toorn (Eds.). Architecture in Effect vol \#1(2) Rethinking the Social in Architecture: Making Effects (pp. 18-35). Barcelona \& New York: Actar.

Hemström, K. (2018). Verktyg för gemensam kunskapsproduktion: Exempel från Mistra Urban Futures plattform i Göteborg 2010-2016. Mistra Urban Futures Report 2018:2. Göteborg: Mistra Urban Futures.

Jonsdotter, L., Femenías, C., \& Holmström, C. (2016). Att bygga och att bo. Intervjuer med 11 hushåll om kvalitet och bostadsanpassning av bostadsrättslägenheter. Göteborg: Chalmers Arkitektur.

Lidström, S. (2017). Aktivt liv i Västra Hamnen. Cykelhuset Ohboy, Va Hamnen, Malmö. cementa(3), 12-16. 
Masnic, M. (2018). Så vill vi bo i framtiden - brf Viva. RUM Bostad(3), 53-62.

Nilsson, F. (2004). Transdisciplinarity and Architectural Design - On Knowledge production through the Practice of Architecture. In H. Dunin-Woyseth \& L. M. Nielsen (Eds.), Discussing transdisciplinarity: Making professions and the new mode of knowledge production. Oslo: AHO The Oslo School of Architecture and Design.

Riksbyggen. (2017). Ungdomsettor i Brf Viva. Göteborg: Riksbyggen EF.

Roos, I. (2017). Chalmers samlar styrkorna. CHALMERS magasin(3-4), 6-11. 